\title{
Microbiological testing of pharmaceuticals and cosmetics in Egypt
}

\author{
Hend Zeitoun, Mervat Kassem, Dina Raafat, Hamida AbouShlieb and Nourhan Fanaki
}

\begin{abstract}
Background: Microbial contamination of pharmaceuticals poses a great problem to the pharmaceutical manufacturing process, especially from a medical as well as an economic point of view. Depending upon the product and its intended use, the identification of isolates should not merely be limited to the United States Pharmacopeia (USP) indicator organisms.

Results: Eighty-five pre-used non-sterile pharmaceuticals collected from random consumers in Egypt were examined for the eventual presence of bacterial contaminants. Forty-one bacterial contaminants were isolated from 31 of the tested preparations. These isolates were subjected to biochemical identification by both conventional tests as well as API kits, which were sufficient for the accurate identification of only 11 out of the 41 bacterial contaminants (26.8\%) to the species level. The remaining isolates were inconclusively identified or showed contradictory results after using both biochemical methods. Using molecular methods, 24 isolates (58.5\%) were successfully identified to the species level. Moreover, polymerase chain reaction (PCR) assays were compared to standard biochemical methods in the detection of pharmacopoeial bacterial indicators in artificially-contaminated pharmaceutical samples.
\end{abstract}

Conclusion: PCR-based methods proved to be superior regarding speed, cost-effectiveness and sensitivity. Therefore, pharmaceutical manufacturers would be advised to adopt PCR-based methods in the microbiological quality testing of pharmaceuticals in the future.

Keywords: Pharmaceutical contaminants, Biochemical identification, Molecular identification, Artificial contamination, Minimum detection limit

\section{Background}

Microbial contamination of pharmaceuticals has been an everlasting problem for researchers as well as pharmaceutical manufacturers worldwide. It can result in the spoilage of the formula by breaking down active ingredients and excipients, affecting the potency, stability and efficacy of the drug [1]. Furthermore, the presence of high numbers of pathogens poses a serious health threat to consumers, especially those who are already ill or in a weakened state [1-3]. Several cases of infection due to contaminated pharmaceuticals were reported in literature [4-6].

\footnotetext{
*Correspondence: mervat.kassem@alexu.edu.eg; mrvtkssmalex@yahoo.com Department of Pharmaceutical Microbiology, Faculty of Pharmacy, Alexandria University, Alexandria 1 Khartoum Square, Azarita, Alexandria 21521, Egypt
}

Common pharmaceutical contaminants include bacteria, where contamination with Gram-positive bacteria implicates human intervention as a major reason for product contamination, while the presence of Gramnegative bacteria suggests lack of process control in pharmaceutical environments, especially involving water systems and raw materials [4]. Gram-negative rods are considered the most commonly found bacterial isolates in non-sterile pharmaceuticals, regardless of geographical location or time $[4,7]$.

Conventional standard microbiological methods are currently used for the routine testing of pharmaceutical products and identification of pharmaceutical bacterial contaminants, including conventional pharmacopoeial methods, as well as simplified, commercially available biochemical test kits, such as the API system $[8,9]$. Recently, however, molecular technologies have positively affected the field of pharmaceutical microbiology, providing 
rapid quantitative as well as qualitative information on microorganisms present in a given pharmaceutical sample [10-12]. The $16 S$ rRNA gene is most commonly used for taxonomic purposes $[13,14]$.

The objective of this study was to identify bacterial contaminants, isolated from different pharmaceuticals using conventional biochemical methods and the API identification system. Bacterial isolates showing inconclusive or contradictory results were further subjected to polymerase chain reaction (PCR)-based methods of identification using either universal or species-specific primer pairs.

Moreover, this study aimed at comparing between standard biochemical methods and PCR-based assays in the detection of pharmacopoeial bacterial indicators in artificially-contaminated pharmaceutical samples with respect to time, cost and limit of detection.

\section{Methods}

\section{Standard bacterial strains}

The following standard strains were used: Staphylococcus aureus ATCC 6538P, Staphylococcus epidermidis ATCC 12228, Bacillus subtilis ATCC 6633, Bacillus cereus ATCC 14579, Escherichia coli NCTC 10418, Klebsiella pneumoniae ATCC 13883, Salmonella enterica subspecies enterica ATCC 14028, and Pseudomonas aeruginosa ATCC 9027.

\section{Tested pharmaceuticals}

A total of 85 used pharmaceuticals (taken after verbal consent from the consumers) were tested for bacterial contamination. These included 28 pharmaceutical preparations, 33 cosmetic preparations, 17 raw materials and 7 herbal products.

\section{Isolation of contaminants}

One gram (or $10 \mathrm{ml}$ ) of the tested pharmaceutical were aseptically added to $20 \mathrm{ml}$ of sterile tryptic soy broth (TSB) with or without PLT (polysorbate-20 $5 \% \mathrm{v} / \mathrm{v}$, lecithin $0.3 \% \mathrm{w} / \mathrm{v}$, thioglycolate $0.01 \% \mathrm{w} / \mathrm{v}$ ) as a neutralizing agent [15] and incubated at $37^{\circ} \mathrm{C}$ for $24-48 \mathrm{~h}$ in a shaking incubator at $110 \mathrm{rpm}$. Fifty microliters $(\mu \mathrm{l})$ aliquots of the overnight cultures were then streaked onto nutrient agar plates and incubated at $37{ }^{\circ} \mathrm{C}$ for $24 \mathrm{~h}$.

\section{Identification of the bacterial isolates by biochemical tests}

After Gram-staining, the bacterial isolates were identified according to the "Identification flow charts" of Bergey's Manual of Determinative Bacteriology [16].

The Gram-positive cocci were streaked onto the surface of mannitol salt agar (MSA), and then identified by subjecting them to confirmatory tests specific for Staphylococcus spp., including catalase test, tube coagulase test, DNase test, blood hemolysis, urease test and novobiocin sensitivity test. The tested isolates were further identified using the API Staph kit (BioMérieux, France) according to the manufacturer's instructions. Sporulating, rod-shaped Gram-positive isolates were subjected to spore staining to confirm the presence of Bacillus spp. They were subsequently subjected to biochemical tests, namely starch hydrolysis (test for amylase), Voges Proskauer and catalase tests [16-19].

On the other hand, Gram-negative isolates were respectively streaked onto the surface of both MacConkey's agar and cetrimide agar. Oxidase-negative Gram-negative isolates, growing only on MacConkey's agar (enterobacteria) were further identified using various biochemical tests including indole production, methyl red, Voges Proskauer, citrate utilization, urease, oxidative/fermentative activity, motility tests as well as growth on triple sugar iron agar and xylose lysine desoxycholate agar [17, 20, 21]. Further biochemical identification of Gram-negative isolates was done using the API 20E kit (BioMérieux, France).

\section{PCR-based identification \\ Identification using species-specific primer pairs}

PCR-based identification of a specific bacterial species was carried out using a DNA extraction protocol [22], and the species-specific primer pairs were designed using the Standard Nucleotide Basic Local Alignment Search Tool (BLAST) [23]. The adopted species-specific primer pairs and universal primer pairs are listed in Table 1.

Six species-specific primer pairs for S. hominis, S. warneri [24], S. epidermidis [25], B. subtilis, B. cereus and B. anthracis [26] were used for further identification of selected staphylococcal and Bacillus isolates, respectively, by a simple uniplex PCR-based method. Appropriate positive and negative controls were included to exclude false negative and false positive results [27]. The primers for S. epidermidis ATCC 12228, S. warneri isolate (36), B. subtilis ATCC 6633 and B. cereus ATCC 14579 were used as the positive controls for their respective strains, whereas the $16 S r R N A$ universal primer pair was used as a positive control for $S$. hominis and B. anthracis. On the other hand, S. aureus ATCC 6538P was used as the negative control for $S$. epidermidis, S. warneri and $S$. hominis. In addition, B. cereus ATCC 14579 was used as a negative control for $B$. subtilis while $B$. subtilis ATCC 6633 acted as a negative control for B. cereus and $B$. anthracis.

The protocol of amplification for all of the tested bacterial species was as follows: $12.5 \mu \mathrm{l}$ of $2 \times$ Green PCR master mix (DreamTaq ${ }^{\mathrm{Tis}}$, Fermentas Life Sciences, France), $5 \mu \mathrm{l}$ DNA template (10 pg-1 $\mu \mathrm{g}), 0.4 \mu \mathrm{M}$ of each primer, and $5.5 \mu \mathrm{l} \mathrm{PCR}$-grade water.

The PCR reactions were performed using a Perkin Elmer thermocycler (Gene Amp PCR system 2400, 
Table 1 PCR primers used in this study

\begin{tabular}{|c|c|c|c|c|c|}
\hline $\begin{array}{l}\text { Bacterial target/Primer } \\
\text { name }\end{array}$ & $\begin{array}{l}\text { Forward }(\mathrm{F}) \text { and Reverse }(\mathrm{R}) \text { primer } \\
\text { Annealing temperature }\left(\mathrm{tm}-5^{\circ} \mathrm{C}\right)\end{array}$ & $\begin{array}{l}\text { Nucleo-tide } \\
\text { positions }^{a}\end{array}$ & Gene amplified & $\begin{array}{l}\text { PCR product } \\
\text { size (bp) }\end{array}$ & Ref. \\
\hline \multirow[t]{3}{*}{ Universal primer pair } & F: 5'AGAGTTTGATCMTGGCTCAG3' & NP & $16 S$ rRNA & 1500 & [27] \\
\hline & R: 5'TACGGYACCTTGTTACGACTT3' & & & & \\
\hline & $\left(46.8^{\circ} \mathrm{C}\right)$ & & & & \\
\hline \multirow[t]{3}{*}{ S. hominis } & F: 5'GTTCGATAGTGAAAGATGGCTC3' & NP & $16 S$ rRNA & 833-852 & [24] \\
\hline & R: 5'GGAAACTTCTATCTCTAGAAGG3' & & & & \\
\hline & $\left(43.4^{\circ} \mathrm{C}\right)$ & & & & \\
\hline \multirow[t]{3}{*}{ S. warneri } & F: 5'GGTTCAATAGTGAAAGGCGGC3' & NP & 165 rRNA & $833-852$ & [24] \\
\hline & R: 5'GGAAGACTCTATCTCTAGAGC3' & & & & \\
\hline & $\left(41.1^{\circ} \mathrm{C}\right)$ & & & & \\
\hline \multirow[t]{3}{*}{ S. epidermidis } & $\begin{array}{l}\text { F: 5' } \\
\text { TCTCTITTAATTTCATCTTCAATTCCATAG3' }\end{array}$ & $448-477$ & $\mathrm{~b}$ & 174 & [25] \\
\hline & $\begin{array}{l}\text { R: 5' } \\
\text { AAACACAATTACAGTCTGTTATCCATATC3' }\end{array}$ & $593-622$ & & & \\
\hline & $\left(54^{\circ} \mathrm{C}\right)$ & & & & \\
\hline \multirow[t]{3}{*}{ B. anthracis } & F: 5'AATCGTAATATTAAACTGACG3' & $607-627$ & gyrB & 244 & [26] \\
\hline & R: 5'CCTTCATACGTGTGAATGTTG3' & $831-851$ & & & \\
\hline & $\left(40.5^{\circ} \mathrm{C}\right)$ & & & & \\
\hline \multirow[t]{3}{*}{ B. cereus } & F: 5'ATTGGTGACACCGATCAAACA3' & $490-510$ & gyrB & 364 & [26] \\
\hline & R: 5'TCATACGTATGGATGTTATTC3' & $834-854$ & & & \\
\hline & $\left(41^{\circ} \mathrm{C}\right)$ & & & & \\
\hline \multirow[t]{3}{*}{ B. subtilis } & F:5'CAGTCAGGAAATGCGTACGTC CTT3' & $N P$ & gyrA & 1027 & [26] \\
\hline & R:5'CAAGGTAATGCTCCAGGCATTGCT3' & & & & \\
\hline & $\left(57.2^{\circ} \mathrm{C}\right)$ & & & & \\
\hline \multirow[t]{3}{*}{ S. aureus } & F: 5'GCGATTGATGGTGATACGGTT3' & $48-70$ & nucA (nuclease A) & 280 & [32] \\
\hline & R: 5'AGCCAAGCCTTGACGAACTAA AGC3' & $303-328$ & & & \\
\hline & $\left(55^{\circ} \mathrm{C}\right)$ & & & & \\
\hline \multirow[t]{3}{*}{ E. coli } & F: 5'AAAACGGCAAGAAAAAGCAG3' & $754-773$ & uidA ( $\beta$-D-glucuro-nidase) & 147 & [31] \\
\hline & R: 5'ACGCGTGGTTACAGTCTTGCG3' & $880-900$ & & & \\
\hline & $\left(50.7^{\circ} \mathrm{C}\right)$ & & & & \\
\hline \multirow[t]{3}{*}{ S. enterica } & F: 5'ATCGCCACGTTCGGGCAATTC3' & NP & invA (invasion protein) & 275 & [33] \\
\hline & R: 5'ACGGTTCCTITGACGGTGCGAT3' & & & & \\
\hline & $\left(55^{\circ} \mathrm{C}\right)$ & & & & \\
\hline \multirow[t]{3}{*}{ P. aeruginosa } & F: 5'ATGGAAATGCTGAAATTCGGC3' & NP & oprL (membrane & 504 & {$[28$,} \\
\hline & R: 5'CTTCTTCAGCTCGACGCGACG3' & & & & \\
\hline & $\left(55^{\circ} \mathrm{C}\right)$ & & & & \\
\hline
\end{tabular}

${ }^{a}$ Nucleotide positions: refers to the positions of the nucleotides on the target gene where the forward and reverse primers anneal

${ }^{\mathrm{b}} \mathrm{A}$ genomic DNA fragment with unknown coding potential

NP Not Provided

USA), with an initial denaturation at $95{ }^{\circ} \mathrm{C}$ for $5 \mathrm{~min}$, followed by 30 cycles at $95^{\circ} \mathrm{C}(0.5 \mathrm{~min}), \mathrm{Tm}-5(0.5 \mathrm{~min})$ and $72{ }^{\circ} \mathrm{C}(0.5-1.5 \mathrm{~min})$ and a final extension at $72{ }^{\circ} \mathrm{C}$ for $10 \mathrm{~min}$. The extension time during the 30 cycles was chosen based on the product size $(1 \mathrm{~min} / \mathrm{kb})$.

The amplified samples were then analyzed by agarose gel electrophoresis using 1-1.5\% agarose gels (Fischer
Scientific ${ }^{\circ}$, UK) that had been prestained with ethidium bromide (Fischer Scientific, Canada).

\section{Identification using $16 S$ rRNA universal primer pair}

Identification of selected bacterial isolates was done by PCR amplification of the $16 S r R N A$ gene using universal primer pair [28, 29], followed by $16 S r R N A$ gene 
sequencing of the amplified PCR products. Genomic bacterial DNA isolation kit (Biospin Bacteria Genomic DNA Extraction Kit, Cat\# BSC12S1, China) was used to extract highly pure DNA, which was used for downstream molecular experiments, including DNA sequencing. Each PCR reaction tube (final volume, $50 \mu \mathrm{l}$ ) contained the following: $25 \mu \mathrm{l}$ of $2 \times$ Green PCR master mix (DreamTaq ${ }^{\text {tax }}$, Fermentas Life Sciences, France), $7 \mu \mathrm{l}$ DNA extract $(10 \mathrm{pg}-1 \mu \mathrm{g}), 0.6 \mu \mathrm{M}$ of each primer, and $12 \mu \mathrm{l}$ PCR-grade water. A negative control was prepared by replacing the DNA template with sterile deionized water (DiW). The PCR reaction was performed with an initial denaturation at $95{ }^{\circ} \mathrm{C}$ for $5 \mathrm{~min}$, followed by 30 cycles at $95{ }^{\circ} \mathrm{C}, 46.8{ }^{\circ} \mathrm{C}$ and $72{ }^{\circ} \mathrm{C}$ for $0.5 \mathrm{~min}, 0.5 \mathrm{~min}$ and $1.5 \mathrm{~min}$, respectively and a final extension at $72{ }^{\circ} \mathrm{C}$ for $10 \mathrm{~min}$. The final PCR product was purified by the company Sigma for Scientific Services (Cairo, Egypt) prior to DNA sequencing of the 16S rRNA gene with the help of a Bioneer automated sequencer (Bioneer 3730xl, USA), using forward and reverse $16 S$ rRNA universal primer pairs $[28,29]$.

\section{Sequence alignments and construction of phylogenetic trees}

Using the Nucleotide Basic Local Alignment Search Tool (BLAST) [30], the nucleotide sequences were compared against the GenBank database. The top twenty homology matched hits for each isolate, with the highest total score, were then used together with the isolate sequence to construct a phylogenetic tree using the BLAST program.

\section{Artificial contamination of a pharmaceutical sample}

Ten-gram samples of raw material glucose powder were added to $100 \mathrm{ml}$ of TSB. After thorough dissolution, samples were inoculated separately with $1 \mathrm{ml}$ of a $10^{-6}$ dilution of 24-h TSB cultures of either $P$. aeruginosa ATCC 9027, E. coli NCTC 10418, S. aureus ATCC 6538P or S. enterica subsp. enterica ATCC 14028. Inoculated samples were placed in a shaking incubator for $24 \mathrm{~h}$ at $37^{\circ} \mathrm{C}$ and $100 \mathrm{rpm}$.

\section{Standard methods for isolation and detection of bacterial contaminants}

After incubation, the enriched TSB cultures were streaked on MacConkey's agar, MSA, cetrimide agar and Xylose-Lysine-Desoxycholate (XLD) agar plates. After incubation at $37{ }^{\circ} \mathrm{C}$ for $24-48 \mathrm{~h}$, colonies were streaked onto sterile plates of trypticase soy agar (TSA) for isolation of pure cultures. TSA plates were incubated for 18$24 \mathrm{~h}$ and cells from pure cultures were Gram-stained and then subjected to biochemical identification tests. Additionally, API 20E and API Staph kits were used for further biochemical identification.

\section{DNA extraction from artificially-contaminated samples}

Three ml-aliquots of the artificially-contaminated samples were centrifuged for $10 \mathrm{~min}$ at $14000 \mathrm{rpm}$. The pellet was washed twice in $1 \mathrm{ml}$ of sterile DiW, then resuspended in $1 \mathrm{ml}$ of sterile DiW and boiled for 10-15 min followed by centrifugation at $14000 \mathrm{rpm}$ for $5 \mathrm{~min}$. The supernatant was used as a source of DNA for the PCR reaction.

\section{PCR detection of bacterial contaminants}

For each sample, $10 \mu \mathrm{l}$ of the DNA lysate $(10 \mathrm{pg}-1 \mu \mathrm{g})$ were transferred into a PCR tube containing $12.5 \mu \mathrm{l} 2 \times$ Green PCR master mix (DreamTaq ${ }^{\text {TM }}$, Fermentas Life Sciences, France), $0.4 \mu \mathrm{M}$ of each primer (Table 1), and $0.5 \mu \mathrm{l}$ PCR-grade water. The simple uniplex PCR reaction conditions were optimized for the different speciesspecific primer pairs for each bacterial contaminant [28, $29,31-33]$, so that they could be used in a single PCR run with an initial denaturation at $95{ }^{\circ} \mathrm{C}$ for $5 \mathrm{~min}$, followed by 40 cycles at $95{ }^{\circ} \mathrm{C}, 55{ }^{\circ} \mathrm{C}$ and $72{ }^{\circ} \mathrm{C}$ for 0.5 $\mathrm{min}, 0.5 \mathrm{~min}$ and $0.75 \mathrm{~min}$, respectively, and a final extension at $72{ }^{\circ} \mathrm{C}$ for $10 \mathrm{~min}$.

\section{Determination of Minimum Detection limit (MDL) for both methods under investigation}

The MDL of each method was determined by using standard E. coli NCTC 10418 as a representative of bacterial contaminants. The pharmaceutical product used was $10 \%$ glucose solution prepared aseptically by adding $10 \mathrm{gm}$ glucose powder to $100 \mathrm{ml}$ sterile distilled water.

A TSB culture of E. coli NCTC 10418 was diluted in $0.9 \%$ sterile saline to prepare a series of 10 -fold dilutions. The $10 \%$ glucose solutions were separately inoculated with the above mentioned dilutions to contain about $10^{7}-10^{2} \mathrm{CFU} / \mathrm{ml}$ for each of the tested methods. To determine the MDL for conventional biochemical methods; a loopful of each inoculated sample was streaked onto selective media (MacConkey's agar and XLD agar) as well as TSA plates. The MDL was estimated based on the least inoculum $(\mathrm{CFU} / \mathrm{ml}$ of the sample) showing growth on agar plates.

To determine the MDL for PCR-based methods, the following was done: $1 \mathrm{ml}$ of each inoculated sample was centrifuged at $14000 \mathrm{rpm}$ for $10 \mathrm{~min}$. The supernatant was discarded and the pellet was resuspended in $5 \mu \mathrm{l}$ sterile DiW which was then transferred into a PCR tube that was then heated at $95{ }^{\circ} \mathrm{C}$ for $10 \mathrm{~min}$ to extract DNA. The remaining PCR components were then added to the PCR tube: $12.5 \mu \mathrm{l}$ of $2 \times$ Green PCR master mix (DreamTaq $^{\text {Tw, }}$, Fermentas Life Sciences, France), $0.4 \mu \mathrm{M}$ of each primer, and $5.5 \mu \mathrm{l}$ PCR-grade water.

Using the species-specific primer pair for E. coli $[29,31]$, the reaction was performed with an initial denaturation at $95{ }^{\circ} \mathrm{C}$ for $5 \mathrm{~min}$, followed by 30 cycles at 
$95^{\circ} \mathrm{C}, 50.7^{\circ} \mathrm{C}$ and $72^{\circ} \mathrm{C}$ for 0.5 min each, and a final extension at $72^{\circ} \mathrm{C}$ for $10 \mathrm{~min}$.

\section{Results}

A total of 85 pre-used pharmaceuticals (Additional file 1) were collected and examined for the eventual presence of bacterial contaminants. The samples were collected from different available classes of preparations including syrups, elixirs, drops (eye, ear and oral), powders, teabags and cosmetics. In total, 41 bacterial contaminants were successfully isolated from 31 of the tested pharmaceuticals, i.e., bacterial contaminants were found in $36.5 \%$ of the tested products. These contaminants were distributed as follows: 9 from 28 pharmaceutical preparations, 10 from 17 raw materials, 12 from 33 cosmetic preparations and 10 from 7 herbal products. Gram-positive bacteria were more prevalent than Gram-negative bacteria in the tested products, where they constituted $88.9 \%(8 / 9), 91.7 \%(11 / 12)$ and $100 \%(10 / 10)$ of the detected contaminants in pharmaceutical preparations, cosmetic preparations and raw materials, respectively. On the other hand, 9 out of the 10 contaminants in herbal products were Gram-negative bacteria.

Following their isolation, the bacterial contaminants were subjected to biochemical identification, using conventional tests as well as API identification systems. Selected isolates, which showed inconclusive or contradictory results, were further identified using PCR-based methods.

\section{Biochemical identification of the bacterial isolates}

Among the isolated contaminants, 30 isolates were Gram-positive (12 coagulase-negative staphylococci, 16
Bacillus spp., one Kocuria/Micrococcus spp. and one Gram-positive non-spore-forming rod), whereas the remaining 11 isolates were thin short Gram-negative rods (10 enterobacterial isolates and one Pseudomonas spp.).

Based on the biochemical identification results of the 13 Gram-positive cocci (Table 2), six isolates were accurately identified by both conventional methods and the API Staph system. On the other hand, the remaining 7 isolates and the Gram-positive, non-spore-forming, rodshaped isolate $24 \mathrm{~B}$ were not conclusively identified, and were thus further subjected to PCR-based methods to achieve proper identification.

The Bacillus contaminants, representing 39\% of the isolated contaminants, were isolated from the tested raw materials, and their identity was confirmed by differential biochemical tests, including starch hydrolysis, Voges Proskauer and catalase tests (Additional file 2).

Based on the biochemical identification results of the 11 Gram-negative isolates (Table 3), only five were conclusively identified using both conventional methods and the API 20E system.

\section{Molecular identification using PCR-based methods}

Species-specific primer pairs were used whenever the results of the conventional and the API methods were contradictory, or when further identification to the species level was required. This pertained to 5 staphylococcal isolates (17, 20A, 44, 52 and 62; Table 1), as well as all of the Bacillus isolates. Two of the former isolates (20A and 52) showed a PCR product at the specified

Table 2 Identification of Gram-positive cocci using conventional biochemical methods and API Staph kit

\begin{tabular}{|c|c|c|c|c|}
\hline \multirow{2}{*}{$\begin{array}{l}\text { Isolate } \\
\text { code }\end{array}$} & \multirow{2}{*}{$\begin{array}{l}\text { Identification based on } \\
\text { conventional biochemical tests }\end{array}$} & \multicolumn{2}{|l|}{ Identification based on API Staph kit } & \multirow[t]{2}{*}{ Final conclusion } \\
\hline & & Result (\%|D) & Level of discrimination & \\
\hline $16 \mathrm{~A}$ & S. epidermidis & S. epidermidis (95.3\%) & Good & S. epidermidis ${ }^{\text {a }}$ \\
\hline $16 \mathrm{~B}$ & \multirow{2}{*}{$\begin{array}{l}\text { S. hominis, S. cohnii, S. saprophyticus, } \\
\text { S. xylosus, S. simulans or S. warneri }\end{array}$} & S. saprophyticus (64.6\%) & Not valid & $b$ \\
\hline 17 & & S. warneri (61.5 \%), S. hominis (35.5 \%) & Good to genus & S. warneri or S. hominis ${ }^{\mathrm{C}}$ \\
\hline $20 \mathrm{~A}$ & S. epidermidis & S. auricularis (83.9 \%) & Good to genus & $d$ \\
\hline $20 B$ & S. epidermidis & S. epidermidis (96.1\%) & Good & S. epidermidis ${ }^{a}$ \\
\hline 22 & S. epidermidis & S. hominis (46 \%), S. warneri (21.3\%) & Not valid & b \\
\hline 23 & S. haemolyticus & S. haemolyticus (88.9 \%) & Acceptable & S. haemolyticus ${ }^{\mathrm{a}}$ \\
\hline $24 \mathrm{~A}$ & Micrococcus spp. & Kocuria varians/rosea (97.8\%) & Good & Kocuria varians ${ }^{a}$ \\
\hline 36 & \multirow{2}{*}{$\begin{array}{l}\text { S. hominis, S. cohnii, S. saprophyticus, } \\
\text { S. xylosus, S. simulans or S. warneri }\end{array}$} & S. warneri (89.9\%) & Good to genus & S. warneri \\
\hline 44 & & S. warneri (61.5 \%), S. hominis (35.5 \%) & Good to genus & S. warneri or S. hominis ${ }^{c}$ \\
\hline 52 & S. epidermidis & S. chromogenes (72.2\%) & Good to genus & $d$ \\
\hline $57 \mathrm{~A}$ & S. epidermidis & S. epidermidis (98.1\%) & Good & S. epidermidis ${ }^{a}$ \\
\hline 62 & $\begin{array}{l}\text { S. hominis, S. cohnii, S. saprophyticus, } \\
\text { S. xylosus, S. simulans or S. warneri }\end{array}$ & S. warneri (61.5 \%), S. hominis (35.5\%) & Good to genus & S. warneri or S. hominis \\
\hline
\end{tabular}

${ }^{a}$ Molecular identification was not deemed necessary

${ }^{\mathrm{b}}$ The isolate was not properly identified by biochemical methods and therefore molecular identification was required

${ }^{c}$ Further identification to the exact Staphylococcus sp. using molecular methods was required

${ }^{d}$ Contradictory identification results using biochemical methods necessitate the use of molecular identification 
Table 3 Identification of Gram-negative isolates using biochemical methods

\begin{tabular}{|c|c|c|c|c|}
\hline \multirow{2}{*}{$\begin{array}{l}\text { Isolate } \\
\text { code }\end{array}$} & \multirow{2}{*}{$\begin{array}{l}\text { Identification based on conventional } \\
\text { biochemical tests }\end{array}$} & \multicolumn{2}{|l|}{ Identification based on API $20 \mathrm{E}$ kit } & \multirow[t]{2}{*}{ Final conclusion } \\
\hline & & Result (\%ID) & Level of discrimination & \\
\hline 1 & Erwinia cacticida or Erwinia dissolvens & Ent. cloacae (94.3\%) & Good & 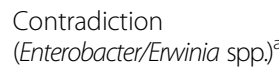 \\
\hline $8 \mathrm{~A}$ & $\begin{array}{l}\text { Providencia alcalifaciens, Providencia } \\
\text { rustigianii or Providencia stuartii }\end{array}$ & Providencia alcalifaciens/rustigianii (72 \%) & $\begin{array}{l}\text { Very good identification } \\
\text { to the genus }\end{array}$ & $\begin{array}{l}\text { Providencia alcalifaciens/ } \\
\text { rustigianili }^{\mathrm{a}}\end{array}$ \\
\hline $11 \mathrm{~A}$ & $\begin{array}{l}\text { Ent. aerogenes or K. pneumoniae subsp. } \\
\text { pneumoniae }\end{array}$ & K. pneumoniae subsp. pneumoniae (97.6 \%) & Good & $\begin{array}{l}\text { K. pneumoniae subsp. } \\
\text { pneumoniae }^{a}\end{array}$ \\
\hline $11 \mathrm{~B}$ & Erwinia cacticida & Buttiauxella agrestis (63\%) & Low & $\mathrm{b}$ \\
\hline 12 & Erwinia cacticida or Erwinia dissolvens & $\begin{array}{l}\text { Ent. sakazakii (51.1 \%), } \\
\text { Ent. amnigenus } 1(31.7 \%)\end{array}$ & $\begin{array}{l}\text { Excellent identification } \\
\text { to the genus }\end{array}$ & $\begin{array}{l}\text { Contradiction } \\
(\text { Enterobacter/Erwinia } \\
\text { spp. })^{\mathrm{a}}\end{array}$ \\
\hline $54 \mathrm{~A}$ & Ent. cloacae or Ent. agglomerans & K. pneumoniae subsp. pneumoniae (98 \%) & Good & c \\
\hline $54 \mathrm{~B}$ & K. oxytoca & Ent. sakazakii (99.9\%) & Excellent & c \\
\hline $55 \mathrm{~A}$ & Erwinia cacticida or Serratia entomophila & $\begin{array}{l}\text { Pantoea spp. } 2 \text { ( } 50.7 \%) \\
\text { K. pneumoniae subsp. pneumoniae (30.4\%) }\end{array}$ & Low & b \\
\hline $55 \mathrm{~B}$ & $\begin{array}{l}\text { Ent. amnigenus, Ent. sakazakii or Ent. } \\
\text { nimipressuralis }\end{array}$ & Ent. sakazakii (98.4 \%) & Good & Ent. sakazakii ${ }^{a}$ \\
\hline 56 & K. oxytoca & Ent. sakazakii (99.9\%) & Excellent & c \\
\hline $82 \mathrm{~A}$ & $\begin{array}{l}\text { Pseudomonas spp. other than } P \text {. } \\
\text { aeruginosa }\end{array}$ & $\begin{array}{l}\text { Non fermentor spp. (32.1\%), } \\
\text { Ochrobactrum anthropi (25.4 \%), } \\
\text { Bordetella/ Alcaligenes/ Moraxella spp. (24.4\%) }\end{array}$ & Low & b \\
\hline
\end{tabular}

${ }^{a}$ Molecular identification was not deemed necessary

${ }^{b}$ The isolate was not properly identified by biochemical methods and therefore molecular identification was required

${ }^{c}$ Contradictory identification results using biochemical methods necessitate the use of molecular identification

band size (174 bp) (Fig. 1) and were thus identified as $S$. epidermidis. The results of the PCR-based identification of these 2 isolates were in agreement with those of conventional biochemical tests, while they contradicted those of the API Staph kit.

The remaining 3 staphylococci (isolates 17, 44 and 62) were not definitively identified by biochemical methods (Table 2), though the API Staph kit results were more useful in guiding us towards choosing the specific primers (S. warneri and S. hominis-specific primers)

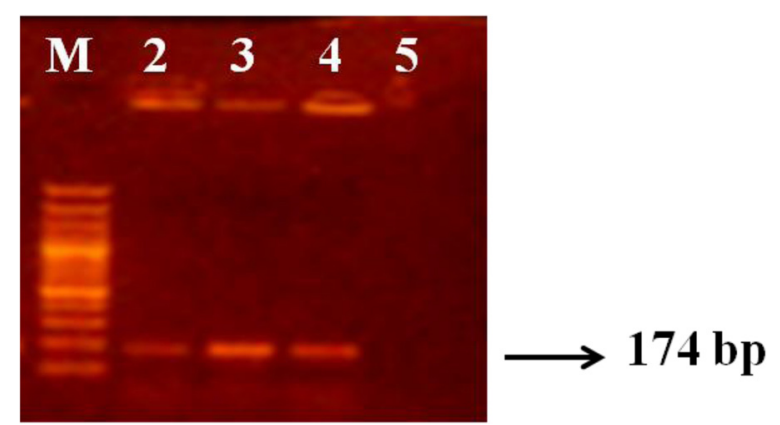

Fig. 1 PCR amplification of specific gene fragment (174 bp) in S. epidermidis. Lane M: 100 bp plus DNA ladder; Lane 2: isolate 20A; Lane 3: isolate 52; Lane 4: positive control (S. epidermidisATCC 12228); Lane 5: negative control (S. aureusATCC 6538P). * DNA ladder yields 14 fragments of the following sizes (bp; from top to bottom): 3000, 2000, 1500, 1200, 1000, 900, 800, 700, 600, 500, 400, 300,200 and 100 used in the PCR-based identification. The 3 isolates were identified as $S$. warneri, since they showed a PCR product at the expected band size (about $850 \mathrm{bp}$ ) upon using the respective species-specific primer pair (Additional file 3).

For further identification of all of the 16 Bacillus isolates, three species-specific primer pairs were used, each was respectively specific to one of the 3 most pathogenic Bacillus spp.; B. anthracis, B. subtilis and B. cereus. None of the Bacillus isolates was identified as B. anthracis, while twelve isolates yielded a PCR product at the specified band size (1027 bp) after PCR amplification using a B. subtilis-specific primer pair (Additional files 4 and 5). It is worth mentioning that, although isolate $8 \mathrm{~B}$ failed to hydrolyse starch when grown on starch agar and isolate 29 showed a negative Voges Proskauer test, they were both still identified as $B$. subtilis using the respective species-specific primer pair. Moreover, only one Bacillus isolate (isolate 13) turned out to be B. cereus, since it showed a PCR product at 364 bp upon using the respective species-specific primer pair (Table 1). As for the remaining three Bacillus isolates, none of them showed a PCR product with any of the three used primer pairs. Consequently, the latter isolates could not be identified by the applied PCR-based method.

The presence of three Gram-negative isolates showing contradictory results between both conventional tests and API 20E kit at the genus level (isolates 54A, 54B 
and 56; Table 3) necessitated the use of a PCR-based method using Enterobacter-specific and Klebsiella-specific primer pairs. However, this was found to be inapplicable, since the two genera share very close genotypic characteristics [34], which was confirmed by checking the specificity of the respective genus-specific primer pairs published in the literature [35-37] and using the BLAST program [23].

On the other hand, the use of the $16 S$ rRNA universal primer pair, followed by gene sequencing, was used whenever biochemical identification results were inconclusive. This applied to; (i) two staphylococcal isolates (16B and 22; Table 2), (ii) the Gram-positive non-sporeforming rod-shaped isolate $24 \mathrm{~B}$, and (iii) three Gramnegative isolates $(11 \mathrm{~B}, 55 \mathrm{~A}$ and $82 \mathrm{~A}$; Table 3$)$. Their identification was achieved by PCR amplification of the conserved $16 S$ rRNA gene $(\sim 1500 \mathrm{bp})$ using a universal primer pair, followed by DNA sequencing of the amplified $16 S$ rRNA gene and construction of phylogenetic trees using the BLAST program. Only three figures representing the three groups mentioned above are shown here (Figs. 2, 3 and 4).

The Gram-positive isolate 16B was found to bear similarity to S. saprophyticus subsp. bovis (phylogenetic tree shown in Fig. 2). This finding coincides with that of the API Staph kit, although the latter's results were considered "invalid" (Table 2).

Using phylogenetic analysis (Additional file 6), the Gram-positive isolate 22 was found to be closely related to $S$. warneri. Since most of $S$. warneri strains are known to be mannitol-fermentors [38], while this isolate was found to be both mannitol non-fermenting and novobiocinsensitive, it was incorrectly identified by conventional biochemical methods as $S$. epidermidis. On the other hand, results of the API Staph for the same isolate showed an invalid identification giving a \%ID of $46 \%$ and $21.3 \%$ for $S$. hominis and S. warneri, respectively (Table 2). Therefore, the molecular identification results of the $S$. warneri isolate 22 somewhat agreed with those of API Staph kit; however, they contradicted those of conventional biochemical tests.

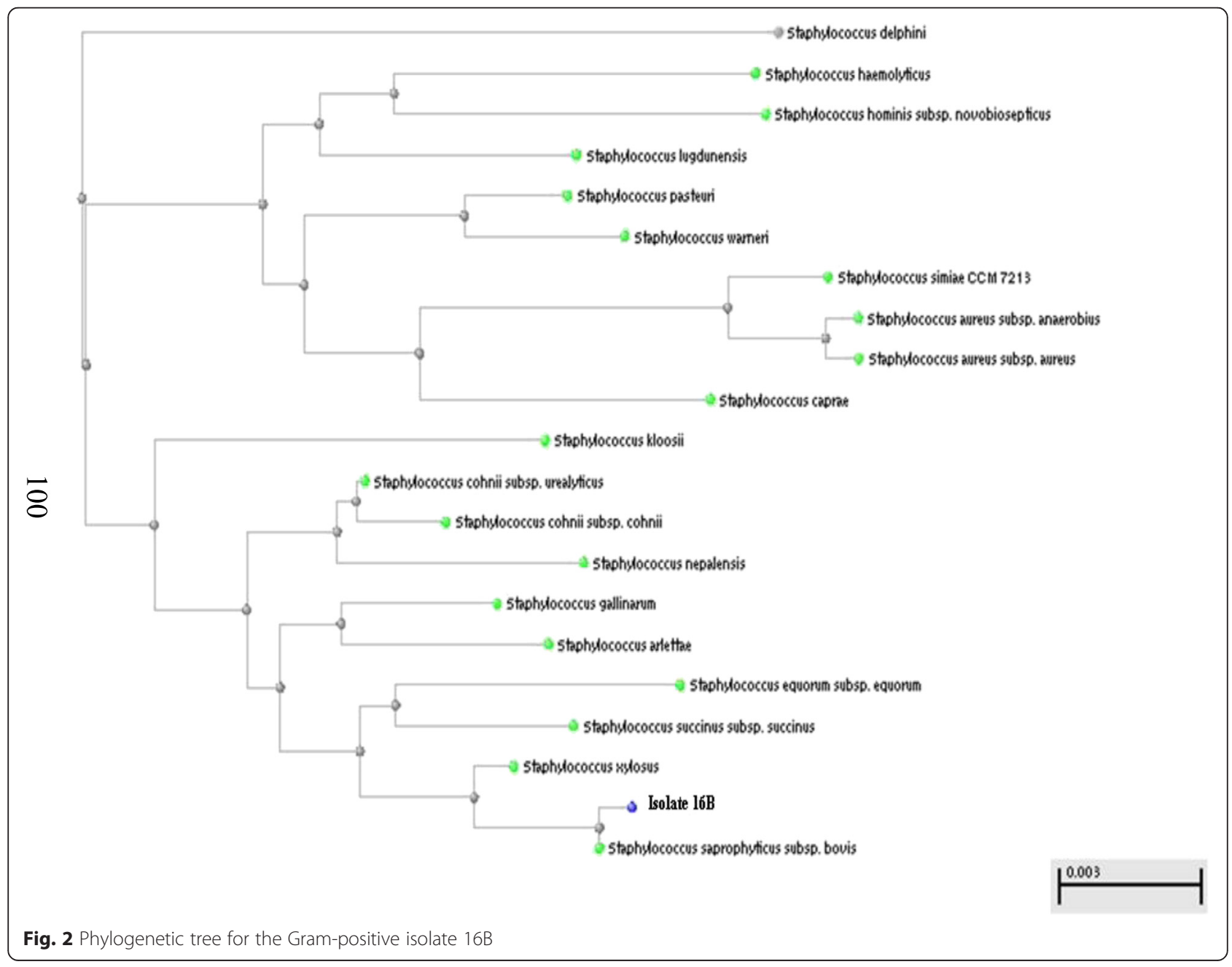




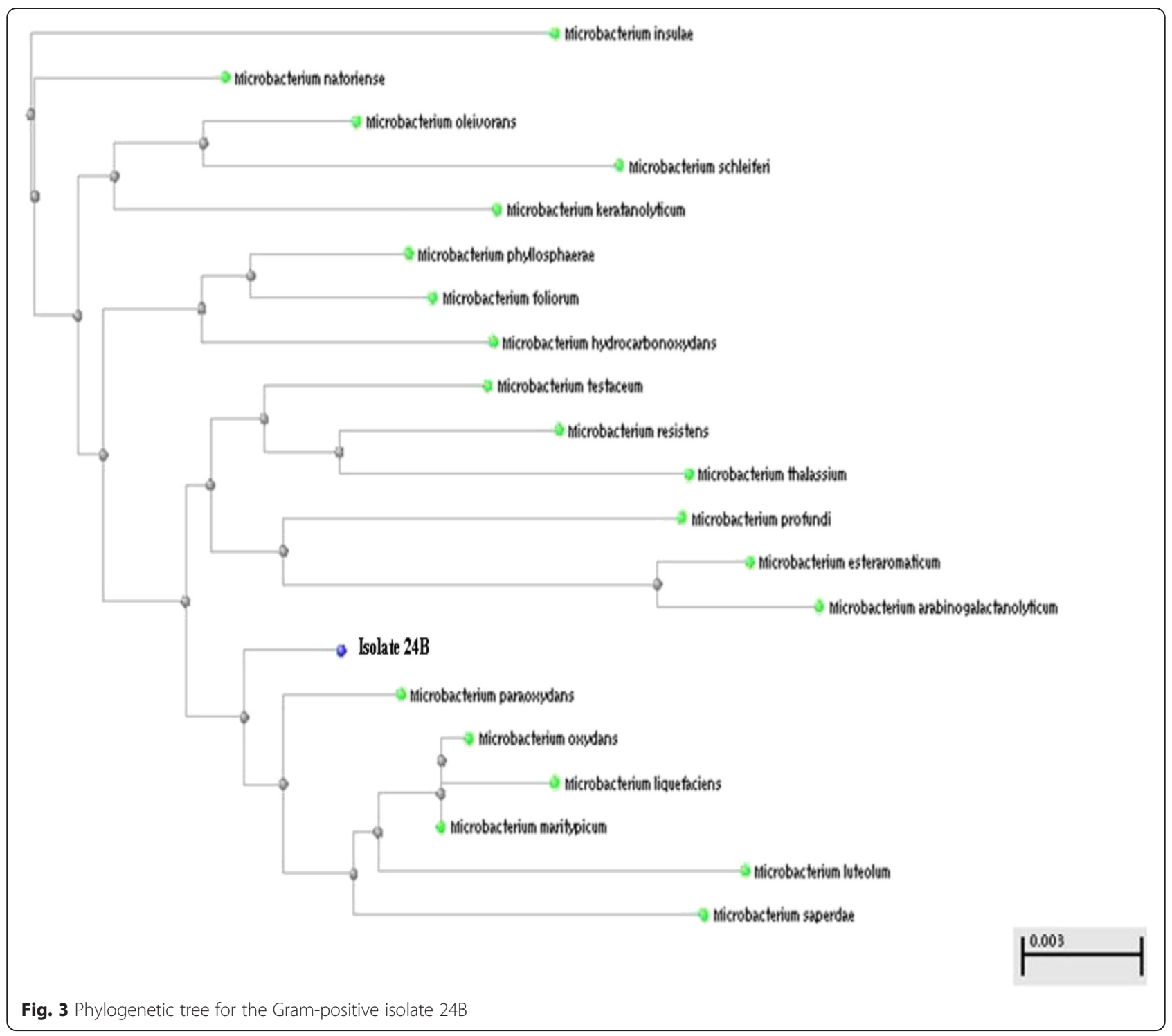

As for the Gram-positive, non-spore-forming, rodshaped isolate $24 \mathrm{~B}$, it was found to be closely related to Microbacterium paraoxydans by phylogenetic analysis (Fig. 3). The identity of this isolate, which did not grow on mannitol salt agar nor MacConkey's agar, could not be determined using the conventional biochemical tests.

Regarding Gram-negative isolates, the phylogenetic tree of isolate 11B (Additional file 7) revealed a close relationship to Pectobacterium cypripedii. The genus Pectobacterium, which includes Gram-negative non-lactosefermentors, is closely related to the genus Erwinia [39]. The molecular identification result is therefore close to that of conventional biochemical tests, which identified this isolate as Erwinia cacticida. On the other hand, the API 20E kit identified the same isolate, though to a low discrimination level, as Buttiauxella agrestis (Table 3). This result confirms the fact that the API 20E kit does not consider lactose fermentation in the differentiation between members of the family Enterobacteriaceae.

The phylogenetic relationship between the Gramnegative isolate 55A and Pantoea agglomerans is illustrated in Fig. 4. This result was in accordance with that of the API 20E kit that identified this isolate as Pantoea spp. (\%ID = 50.7), but with a low level of discrimination. While $K$. pneumoniae subsp. pneumoniae $(\% \mathrm{ID}=30.4)$ came in second place in the API kit identification, it did not even appear in the phylogenetic tree of the isolate.

Finally, the Gram-negative isolate $82 \mathrm{~A}$ was found to be closely related to P. stutzeri LMG 11199T (Additional file 8), which, in turn, is in accordance with conventional biochemical tests, where it was identified as Pseudomonas spp. other than $P$. aeruginosa (Table 3 ). It is noteworthy that this isolate was not conclusively identified by the API $20 \mathrm{E}$ system where it was merely described as a non- 


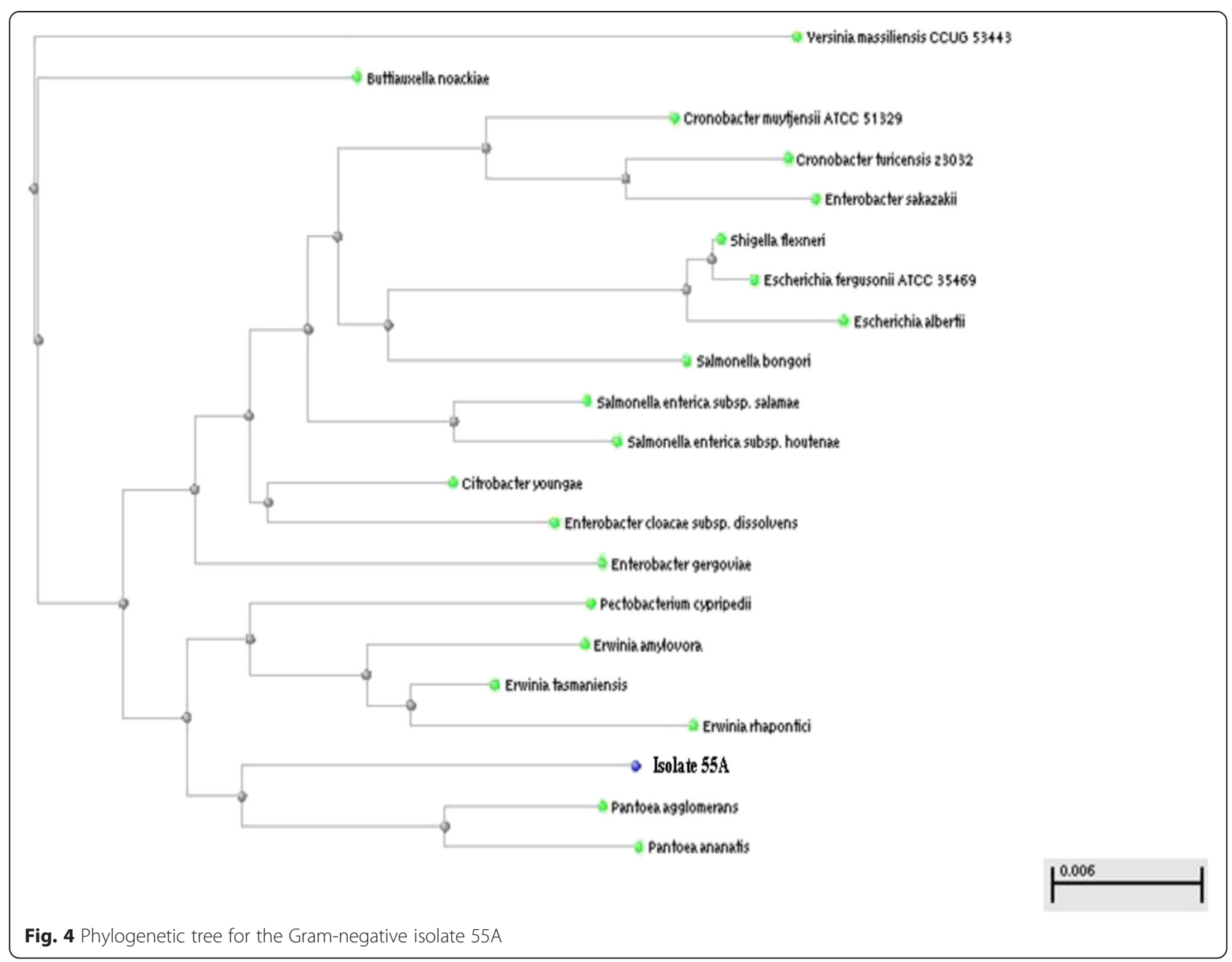

fermentor species with $\% \mathrm{ID}=32.1$, and a low discrimination level.

\section{Artificial contamination of pharmaceutical samples}

Biochemical methods for detecting bacterial contaminants in the pharmaceutical samples involved streaking onto selective/differential agar media for isolation of the target microorganisms. Representative well-isolated bacterial colonies were then transferred to TSA plates for further morphological and biochemical confirmatory identification tests. The standard strains $S$. aureus ATCC 6538P and E. coli NCTC 10418 were subjected to biochemical analysis using the API identification system. $S$. aureus was misidentified as $S$. xylosus with a good identification level, probably due to the fact that the API Staph kit does not include the coagulase test. On the other hand, E. coli was correctly identified using the API $20 \mathrm{E}$ kit, with a very good identification level.

In our study, DNA extraction was achieved by boiling, as suggested by Jimenez et al. [40], since that method was found to be effective for all of the tested bacterial contaminants. The specificity of the different previously reported DNA primer pairs used was confirmed using a BLAST search [41], available through the website of the National Centre for Biotechnology Information (NCBI).

The working concentration of the primer pairs specific to $P$. aeruginosa, E. coli and S. aureus used in PCR was 10 picomoles/ $\mu$ l. However, the $S$. enterica-specific primer pair was used at a higher concentration (20-100 picomoles/ $\mu \mathrm{l})$, in order to show a PCR product.

All of the tested bacterial contaminants were successfully detected in their respective glucose samples by PCR amplification of respective characteristic DNA fragments using species-specific primer pairs (Fig. 5). It should be noted that the PCR product of S. enterica was more intense when using the primer pair at a higher concentration $(100$ picomoles $/ \mu \mathrm{l})$; however, a strong primer dimer band was detected.

A period of 5-7 days was required for the bacteria to be isolated, purified, and identified by biochemical methods. On the other hand, the time needed to complete the PCR assay, including both sample preparation and 


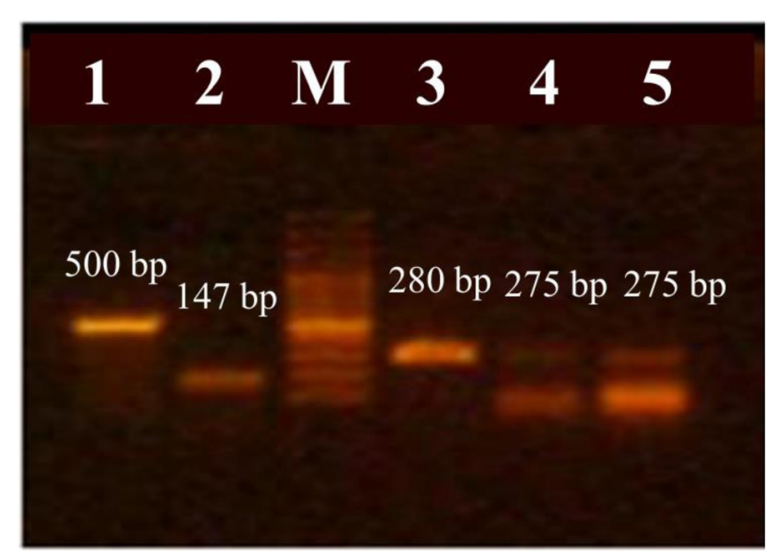

Fig. 5 PCR amplification of specific gene fragments in selected strains. PCR amplification products of the oprL gene fragment (500bp) in P. aeruginosa ATCC 9027 (Lane 1); uidA gene fragment (147 bp) in E. coli NCTC 10418 (Lane 2); nucA gene fragment (280 bp) in S. aureus ATCC 6538P (Lane 3) and invA gene fragment (275 bp) in Sal. enterica ATCC 14028 using 20 picomoles/ $\mu \mathrm{L}$ and 100 picomoles/ $\mu \mathrm{L}$ species-specific primer pair, respectively. Lane $\mathrm{M}$ shows $100 \mathrm{bp}$ plus DNA ladder of fragments sizes (bp; from top to bottom): 3000, 2000, 1500, 1200, 1000, 900, 800, 700, 600, 500, 400 300,200 and 100

PCR amplification of the specific DNA bacterial targets, was only $29-30 \mathrm{~h}$.

The calculated cost of each method included all the steps required to achieve final identification of the selected bacterial contaminants. However, it should be noted that the cost of equipment required for each method was not included. It was found that the cost of culture media, reagents and kits required for the identification of the selected bacterial contaminants by biochemical methods in 4 samples mount to about 373 Egyptian Pounds (L.E.). On the other hand, the cost of the reagents and chemicals required for the PCR-based assay was about 22.7 L.E. for all 4 samples. Although the individual reagents for the PCR assay are relatively more expensive, they are much less in number.

We then estimated the MDL for each identification method under investigation by inoculating $10 \%$ glucose solutions with different inocula $(\mathrm{CFU} / \mathrm{ml})$ of the standard E. coli NCTC 10418. On one hand, the inoculated glucose samples were streaked onto selective agar media as well as TSA plates to determine the least inoculum exhibiting growth. On the other hand, the minimum inoculum showing a detectable PCR band of the specified size on agarose gel was determined by pelleting $1 \mathrm{ml}$ of each inoculated glucose sample and using the pellet as a source of DNA (by heating at $95{ }^{\circ} \mathrm{C}$ for $10 \mathrm{~min}$ ), in order to exclude the effect of the DNA extraction step on the determination of the MDL of the PCR-based method.

We found that the MDL of E. coli using the PCR assay $\left(10^{4} \mathrm{CFU} / \mathrm{ml}\right.$ of sample) was lower than that observed when using conventional methods $\left(10^{5} \mathrm{CFU} / \mathrm{ml}\right.$ of sample).

\section{Discussion}

Microbial contamination of pharmaceuticals may arise during manufacturing, storage or use by the consumer, and can ultimately result in several undesirable consequences. In Egypt, microbiological labs follow the USP and $\mathrm{BP}$ recommendations for testing the presence/load of microbial contaminants in non-sterile dosage forms and dietary supplements.

In the present study, different biochemical (conventional and API) and molecular (PCR-based) methods were used for the identification of a number of bacterial contaminants isolated from various types of pharmaceuticals (including pharmaceutical preparations, cosmetic preparations, herbal products and raw materials). Both of these methods were then compared with regard to the recovery and identification of selected bacterial contaminants.

The bacterial contaminants were isolated from 31 out of 85 pre-used pharmaceutical products tested (36.5\%). Similarly, it was reported earlier that $50 \%$ of the nonsterile pharmaceuticals products tested were heavily contaminated [42]. On the other hand, Campana et al. [1] reported much lower contamination of the tested cosmetic products $(10.6 \%)$. Pre-used products were chosen for this study, in order to increase the probability of finding contaminants. Contaminants isolated from pharmaceutical preparations, cosmetics and raw materials were mostly Gram-positive ( 90.5\%, 19 out of 21 contaminants), while those isolated from herbal products were mostly Gram-negative (90\%, 9 out of 10 contaminants). In agreement with this latter finding, Abba et al. reported that $46.67 \%$ of herbal remedies tested were contaminated with S. typhi, $19.33 \%$ with Shigella spp. and $58.67 \%$ with E. coli [43]. The observed contamination of herbal tea bags in this study with Gramnegative bacteria could be due to any of the following reasons: (i) unsuitable preparation methods; (ii) contaminated materials and equipment; and/or (iii) improper handling of raw materials by infected personnel during processing. In order for herbal preparations to maintain best quality, safety and efficacy, manufacturing companies must ensure the highest level of hygiene during manufacturing, in order to ensure the lowest possible level of pathogenic organisms in their final herbal products. On the other hand, incidents of microbial contamination of cosmetics are widely reported [44-46]. This could be attributed to inadequate preservation of cosmetics or the use of expired products by the public, which in turn can lead to microbial contamination that favors growth and proliferation of skin pathogens upon use [47]. In 2003, Hugbo and colleagues reported that 
microbial contamination was detected in some brands of cosmetic creams, where the most common bacterial contaminants found were Staphylococcus spp. and Bacillus spp., a finding which is similar to ours in the current study [48]. On the other hand, a recent study conducted on non-sterile oral dosage forms found that contaminants were mostly Gram-negative enterobacteria [49].

Compared to cosmetics and pharmaceutical preparations, raw materials showed a higher percentage of contamination (58.8\%), probably due to the lack of effective chemical preservation, where $100 \%$ of the contaminants where Gram-positive bacteria. Our results are in agreement with those of De Clerck et al. who reported that the majority of contaminants isolated from gelatin extracts belonged to members of the genus Bacillus [26].

In the current study, $39 \%$ of the contaminants were identified as Bacillus spp., the majority of which were isolated from non-sterile dosage forms. Similarly, in a recent study from the year 2010, Mugoyela and Mwambete [42] reported that the majority of microbial contaminants isolated from non-sterile pharmaceuticals were Bacillus spp.,

Since only $26.8 \%$ of the isolated contaminants (6 Gram-positive and 5 Gram-negative isolates) were conclusively identified using both conventional methods and the API Staph/API 20E system, molecular identification was deemed necessary for the remaining contaminants. In addition, further identification of Bacillus contaminants to their exact species was not feasible by conventional biochemical tests, since members of the genus Bacillus exhibit a wide range of physiologic versatility, allowing them to live in almost every natural environment $[26,50]$. They therefore required further identification using PCR-based methods using species-specific primer pairs. Similar to conventional biochemical test results, isolates $20 \mathrm{~A}$ and 52 showed a PCR product at the corresponding band size (174 bp), and were thus identified as S. epidermidis. It should be noted that isolate $20 \mathrm{~A}$ was mistakenly identified as $S$. auricularis using the API Staph kit. Although S. auricularis is biochemically similar to $S$. epidermidis, the former is urease-negative [38]. This observed contradiction in the biochemical identification results of isolate 20A most probably arose due to the fact that it gave a positive urease test using the conventional method, whereas it was reported as urease-negative using the API Staph kit. S. chromogenes also has a similar biochemical profile to S. epidermidis; however, isolate 52 was not identified as S. chromogenes, since the latter produces yellow-pigmented colonies upon culturing on nutrient agar [51], unlike isolate 52.

Some identification schemes do not account for phenotypic variations among strains belonging to the same species. For instance, S. saprophyticus is listed in several identification schemes as mannitol nonfermenting, although in our study, one mannitolfermentor, isolate $16 \mathrm{~B}$, was conclusively identified as $S$. saprophyticus by phylogenetic analysis. On the other hand, most of $S$. warneri strains are known to be mannitol-fermentors [38]. This fact resulted in the erroneous identification of the $S$. warneri isolate 22, a mannitol nonfermentor, novobiocin-sensitive and urease-positive staphylococcal isolate, as $S$. epidermidis by conventional biochemical methods. Nevertheless, all five $S$. epidermidis isolates $(16 \mathrm{~A}, 20 \mathrm{~A}, 20 \mathrm{~B}, 52,57 \mathrm{~A})$ were conclusively identified as such by conventional biochemical tests, based on their mannitol non-fermenting, coagulaseand DNAse-negative, novobiocin-sensitive and ureasepositive characteristics.

In this study, both biochemical and PCR-based methods were used to detect bacterial indicators in artificially-contaminated pharmaceutical grade glucose powder, for the purpose of comparing both identification methods with respect to time and cost. Optimization of the PCR reaction conditions for the different primer pairs (annealing temperature: $55^{\circ} \mathrm{C}$; extension time: $45 \mathrm{~s}$ ) was done in the PCR-based identification method, in an attempt to save time. . The PCR reaction conditions optimized in other similar studies $[29,33]$ differed, probably depending on the primer pairs used and the size of the amplicons produced besides the type of DNA polymerase used for amplification.

The relatively long time required by biochemical methods of identification was similar to other studies $[3,10,33,52]$. We therefore concluded that the standard USP procedure [53], which relies primarily on biochemical methods for the identification of bacterial indicators, was both time-consuming and laborintensive. It also requires multiple steps for the growth and isolation of pure bacterial cultures prior to their identification, resulting in delaying the release of raw materials/pharmaceutical products. On the other hand, the relatively short time necessary to conduct a PCR assay was in accordance with previous studies [33, 52]. On estimating the MDL for each identification method, the MDL of E. coli using the PCR assay was lower than that observed using conventional methods. Similarly, Jimenez et al. [54] calculated a MDL of $10^{4} \mathrm{CFU} / \mathrm{ml}$ for Salmonella spp. by a PCR-based method, while a year later, a higher MDL $\left(10^{5} \mathrm{CFU} / \mathrm{ml}\right)$ for E. coli, P. aeruginosa and S. aureus was reported [40]. Conversely, Samadi et al. [55] reported a much lower MDL of $10^{2} \mathrm{CFU} / \mathrm{ml}$. More recently, Farajnia et al. [52] were able to detect microbial contamination at a level of less than $10 \mathrm{CFU} / \mathrm{ml}$ or gram of a product, using a multiplex PCR assay. None of the latter studies calculated an MDL for conventional tests. 


\section{Conclusion}

PCR-based methods provided an earlier, more cost-effective and more sensitive detection and identification of bacterial contamination, compared to standard biochemical methods currently applied in the pharmaceutical industry. This would allow for rapid implementation of corrective actions, thereby minimizing manufacturing losses and speeding up product release.

\section{Additional files}

\section{Additional file 1: Product information of the $\mathbf{8 5}$ tested pharmaceuticals. (DOCX $127 \mathrm{~kb}$ ) \\ Additional file 2: Biochemical tests for the identification of Bacillus isolates. (DOCX $57 \mathrm{~kb}$ )}

Additional file 3: PCR-based identification of staphylococci using species-specific primers. (DOCX $59 \mathrm{~kb}$ )

Additional file 4: PCR amplification of specific gyr $A$ gene fragment (1027 bp) in B. subtilis. Lane M: 100 bp plus DNA ladder*; Lane 1: negative control (B. cereus ATCC 14579); Lane 2: positive control (B. subtilis ATCC 6633); Lane 3: isolate 3A; Lane 4: isolate 3B; Lane 5: isolate 8B; Lane 6: isolate 9; Lane 7: isolate 13; Lane 8: isolate 18; Lane 9: isolate 28; Lane 10: isolate 29; Lane 11: isolate 32; Lane 12: isolate 35; Lane 13: isolate 37; Lane 14: isolate 39; Lane 15: isolate 51; Lane 16: isolate 57B; Lane 17: isolate 63; Lane 18: isolate 82B. * DNA ladder yields 14 fragments. Fragments sizes (bp): 3000, 2000, 1500, 1200, 1000, 900, $800,700,600,500,400,300,200$ and 100. (DOCX $763 \mathrm{~kb}$ )

Additional file 5: PCR amplification of specific gyr $B$ gene fragment (364 bp) in B. cereus. Lane M: 100 bp plus DNA ladder*; Lane 1: negative control (B. subtilis ATCC 6633); Lane 2: positive control (B. cereus ATCC 14579); Lane 3: isolate 3A; Lane 4: isolate 3B; Lane 5: isolate 8B; Lane 6: isolate 9; Lane 7: isolate 13; Lane 8: isolate 18; Lane 9: isolate 28; Lane 10: isolate 29; Lane 11: isolate 32; Lane 12: isolate 35; Lane 13: isolate 37; Lane 14: isolate 39; Lane 15: isolate 51; Lane 16: isolate 57B; Lane 17: isolate 63; Lane 18: isolate 82B. * DNA ladder yields 14 fragments. Fragments sizes (bp): 3000, 2000, 1500, 1200, 1000, 900, 800, 700, 600, 500, 400, 300, 200 and 100. (DOCX $444 \mathrm{~kb}$ )

Additional file 6: Phylogenetic tree for the Gram-positive isolate 22. (DOCX $134 \mathrm{~kb}$ )

Additional file 7: Phylogenetic tree for the Gram-negative isolate 11B. (DOCX $140 \mathrm{~kb}$ )

Additional file 8: Phylogenetic tree for the Gram-negative isolate 82A. (DOCX $142 \mathrm{~kb}$ )

\author{
Abbreviations \\ DiW: Deionized water; L.E.: Egyptian Pounds; MSA: Mannitol salt agar; \\ PCR: Polymerase chain reaction; PLT: Polysorbate-20 5\% v/V, lecithin 0.3\% w/ \\ V, thioglycolate $0.01 \% \mathrm{~W} / \mathrm{v}$; TSA: Trypticase soy agar; TSB: Tryptic soy broth; \\ USP: United States Pharmacopeia; XLD: Xylose-Lysine-Desoxycholate; \\ $\mu \mathrm{l}$ : microliters.
}

\section{Competing interests}

The authors declare that they have no competing interests.

\section{Authors' contributions}

$\mathrm{HZ}$ did all the practical part of the study and prepared the manuscript, MK has been involved in drafting the manuscript and revising it critically. DR has made substantial contributions to conception and designing of the experiments, analysis and interpretation of data. HA coordinated the study and NF designed the study, supervised the work, and finalized manuscript writing. All authors contributed to the preparation and approval of the final manuscript.

\section{Acknowledgements}

We thank the staff of the Department of Microbiology for their help in conducting the experimental part of the study. This study was supported financially by the Faculty of Pharmacy, Alexandria University, Alexandria, Egypt.

Received: 10 May 2015 Accepted: 30 November 2015

Published online: 09 December 2015

\section{References}

1. Campana R, Scesa C, Patrone V, Vittoria E, Baffone W. Microbiological study of cosmetic products during their use by consumers: health risk and efficacy of preservative systems. Lett Appl Microbiol. 2006:43:301-6. http://dx.doi.org/10.1111/j.1472-765X.2006.01952.x.

2. Jimenez $L$. Microorganisms in the environment and their relevance to pharmaceutical processes. In: Jimenez L, editor. Microbial contamination control in the pharmaceutical industry. New York: Marcel Dekker, Inc.; 2004. p. 1-14.

3. Ragheb SM, Yassin AS, Amin MA. The application of uniplex, duplex, and multiplex PCR for the absence of specified microorganism testing of pharmaceutical excipients and drug products. PDA J Pharm Sci Technol. 2012;66:307-17. http://dx.doi.org/10.5731/pdajpst.2012.00871.

4. Jimenez L. Microbial limits. In: Jimenez $\mathrm{L}$, editor. Microbial contamination control in the pharmaceutical industry. New York: Marcel Dekker, Inc; 2004. p. 15-44.

5. Reiss I, Borkhardt A, Fussle R, Sziegoleit A, Gortner L. Disinfectant contaminated with Klebsiella oxytoca as a source of sepsis in babies. Lancet. 2000:356:310. http://dx.doi.org/10.1016/S0140-6736(00)02509-5.

6. Becks V, Lorenzoni NM. Pseudomonas aeruginosa outbreak in a neonatal intensive care unit: a possible link to contaminated hand lotion. Am J Infect Control. 1995;23:396-8. http://dx.doi.org/10.1016/0196-6553(95)90272-4.

7. Labarca JA, Trick WE, Peterson CL, Carson LA, Holt SC SC, et al. Multistate Nosocomial Outbreak of Ralstonia pickettii Colonization Associated with an Intrinsically Contaminated Respiratory Care Solution. Clin Infect Dis. 1999:29:1281-6. doi:10.1086/313458. http://cid.oxfordjournals. org/content/29/5/1281.short.

8. Gemmell CG, Dawson JE. Identification of coagulase-negative Staphylococci with the API staph system. J Clin Microbiol. 1982;16:874-7. http://jcm.asm. org/content/16/5/874.long.

9. Baird R. Contamination of non-sterile pharmaceuticals in hospital and community environments. In: Hugo WB, Russell AD, editors. Pharmaceutical Microbiology. 6th ed. Oxford, UK: Blackwell Science; 1998. p. 374-84.

10. Jimenez L. Molecular applications to pharmaceutical processes and cleanroom environments. PDA J Pharm Sci Technol. 2011;65:242-53. http://dx.doi.org/10.5731/pdajpst.2011.00730

11. Jimenez $L$. Rapid methods for pharmaceutical analysis. In: Jimenez $L$, editor. Microbial contamination control in the pharmaceutical industry. New York: Marcel Dekker, Inc; 2004. p. 147-82

12. Riley BS. Rapid Microbiology Methods in the Pharmaceutical Industry. The review of American pharmaceutical business and technology; 2006. http://www.americanpharmaceuticalreview.com/Featured-Articles/113094Rapid-Microbiology-Methods-in-the-Pharmaceutical-Industry/

13. 3rd Clarridge JE. Impact of 165 rRNA gene sequence analysis for identification of bacteria on clinical microbiology and infectious diseases. Clin Microbiol Rev. 2004;17:840-62. http://dx.doi.org/10.1128/CMR.17.4.840-862.2004.

14. Mignard S, Flandrois JP. 165 rRNA sequencing in routine bacterial identification: a 30-month experiment. J Microbiol Methods. 2006;67:574-81. http://dx.doi.org/10.1016/j.mimet.2006.05.009.

15. Dey BP, Engley Jr FB. Methodology for recovery of chemically treated Staphylococcus aureus with neutralizing medium. Appl Environ Microbiol. 1983;45:1533-7. http://www.ncbi.nlm.nih.gov/pmc/articles/PMC242496/pdf/ aem00174-0123.pdf

16. Identification flow charts. http://www.uiweb.uidaho.edu/micro_biology/250/ ID Flowcharts.pdf, Accessed 7 May 2015.

17. Bergey's Manual of Determinative Bacteriology. Hensyl WR(ed.), 9th edition, Lippincott Williams and Wilkins, Philadelphia: 1994; p. 1, 175-189.

18. Cunha Mde L, Sinzato YK, Silveira LV. Comparison of methods for the identification of coagulase-negative Staphylococci. Mem Inst Oswaldo Cruz. 2004;99:855-60. http://dx.doi.org/10.1590/S0074-02762004000800012.

19. Shittu A, Lin J, Morrison D, Kolawole D. Identification and molecular characterization of mannitol salt positive, coagulase-negative Staphylococci from nasal samples of medical personnel and students. J Med Microbiol. 2006;55:317-24. http://dx.doi.org/10.1099/jmm.0.46072-0. 
20. 3rd Farmer JJ, Davis BR, Hickman-Brenner FW, McWhorter A, Huntley-Carter. Biochemical identification of new species and biogroups of Enterobacteriaceae isolated from clinical specimens. J Clin Microbiol. 1985; 21:46-76. http://jcm.asm.org/content/21/1/46.long.

21. O'Hara CM, Brenner FW, Miller JM. Classification, identification, and clinical significance of Proteus, Providencia, and Morganella. Clin Microbiol Rev. 2000;13:534-46. http://dx.doi.org/10.1128/CMR.13.4.534-546.2000.

22. DNA extraction protocol. http://www.bioprotocols.info/model_organisms/ bacteria/bacteria_colony_pcr.php). Accessed 7 May 2015.

23. The Standard Nucleotide Basic Local Alignment Search Tool (BLAST). http://blast.ncbi.nlm.nih.gov/Blast.cgi?PROGRAM=blastn\&BLAST_ PROGRAMS=megaBlast\&PAGE_TYPE=BlastSearch\&SHOW_

DEFAULTS=on\&LINK_LOC=blasthome. Accessed 7 May 2015

24. Gribaldo S, Cookson B, Saunders N, Marples R, Stanley J. Rapid identification by specific PCR of coagulase-negative Staphylococcal species important in hospital infection. J Med Microbiol. 1997;46:45-53. http://dx.doi.org/10.1099/ 00222615-46-1-45.

25. Martineau F, Picard FJ, Roy PH, Ouellette M, Bergeron MG. Species-specific and ubiquitous DNA-based assays for rapid identification of Staphylococcus epidermidis. J Clin Microbiol. 1996;34:2888-93. http://www.ncbi.nlm.nih.gov/ pmc/articles/PMC229428/pdf/342888.pdf.

26. De Clerck E, Vanhoutte T, Hebb T, Geerinck J, Devos J, De Vos P. Isolation, characterization, and identification of bacterial contaminants in semifinal gelatin extracts. Appl Environ Microbiol. 2004;70:3664-72. http://aem.asm. org/content/70/6/3664.full.pdf.

27. Frank JA, Reich Cl, Sharma S, Weisbaum JS, Wilson BA, Olsen GJ. Critical evaluation of two primers commonly used for amplification of bacterial $16 \mathrm{~S}$ rRNA genes. Appl Environ Microbiol. 2008;74:2461-2470. doi:10.1128/AEM. 02272-07

28. De Vos D, Lim Jr A, Pirnay JP, Struelens M, Vandenvelde C, Duinslaeger L, et al. Direct detection and identification of Pseudomonas aeruginosa in clinical samples such as skin biopsy specimens and expectorations by multiplex PCR based on two outer membrane lipoprotein genes, oprl and oprL. J Clin Microbiol. 1997;35:1295-9. http://jcm.asm.org/content/35/6/1295.long.

29. Jimenez L, Smalls S, Ignar R. Use of PCR analysis for detecting low levels of bacteria and mold contamination in pharmaceutical samples. J Microbiol Methods. 2000;44:259-65. http://dx.doi.org/10.1016/S0167-7012(00)00164-0.

30. Nucleotide Basic Local Alignment Search Tool (BLAST). http://blast.ncbi.nlm. nih.gov/Blast.cgi. Accessed 7 May 2015

31. Bej AK, DiCesare JL, Haff L, Atlas RM. Detection of Escherichia coli and Shigella spp. in water by using the polymerase chain reaction and gene probes for uid. Appl Environ Microbiol. 1991;57:1013-7. http://aem.asm.org/ content/57/4/1013.long.

32. Brakstad OG, Aasbakk K, Maeland JA. Detection of Staphylococcus aureus by polymerase chain reaction amplification of the nuc gene. J Clin Microbiol. 1992;30:1654-60. http://jcm.asm.org/content/30/7/1654.long.

33. Karanam VR, Reddy HP, Subba Raju BV, Rao JC, Kavikishore PB, Vijayalakshmi $M$. Detection of indicator pathogens from pharmaceutical finished products and raw materials using multiplex PCR and comparison with conventional microbiological methods. J Ind Microbiol Biotechnol. 2008;35:1007-18. doi:10.1007/s10295-008-0376-z.

34. Harada $\mathrm{H}$, Ishikawa $\mathrm{H}$. Phylogenetical relationship based on groE genes among phenotypically related Enterobacter, Pantoea, Klebsiella, Serratia and Erwinia species. J Gen Appl Microbiol. 1997;43:355-61. http://dx.doi.org/10. 2323/jgam.43.355.

35. Chander Y, Ramakrishnan MA, Jindal N, Hanson K, Goyal SM. Differentiation of Klebsiella pneumoniae and K. oxytoca by multiplex polymerase chain reaction. Intern J App Res Vet Med. 2011;9:138-42. http://www.jarvm.com/ articles/Nol9lss2 Nol9\%20lss2Goyal.pdf.

36. Otman J, Perugini ME, Tognim MCB, Vidotto MC. Atypical phenotypic characteristics of Klebsiella pneumoniae isolates from an outbreak in a neonatal intensive care unit in Brazil. Braz J Microb. 2007;38:273-7. http://dx.doi.org/10.1590/S1517-83822007000200016.

37. Wang M, Cao B, Yu Q, Liu L, Gao Q, Wang L, et al. Analysis of the 16S-23S rRNA gene internal transcribed spacer region in Klebsiella species. J Clin Microbiol. 2008;46:3555-63. http://dx.doi.org/10.1128/JCM.00927-08.

38. Kloos WE, Schleifer KH. Staphylococcus auricularis sp. nov.: an Inhabitant of the Human External Ear. Int J Syst Bacteriol. 1983;33:9-14. http://dx.doi.org/ 10.1099/00207713-33-1-9.

39. Waleron M, Waleron K, Podhajska AJ, Lojkowska E. Genotyping of bacteria belonging to the former Erwinia genus by PCR-RFLP analysis of a recA gene fragment. Microbiology. 2002;148:583-95. http://mic.sgmjournals.org/ content/148/2/583.long.

40. Jimenez L, Ignar R, Smalls S, Grech P, Hamilton J, Bosko Y, et al. Molecular detection of bacterial indicators in cosmetic/pharmaceuticals and raw materials. J Ind Microbiol Biotechnol. 1999;22:93-5. http://link.springer.com/ article/10.1038/sj.jim.2900611\#page-2.

41. The National Centre for Biotechnology Information. www.ncbi.nlm.nih.gov. Accessed 7 May 2015.

42. Mugoyela V, Mwambete KD. Microbial contamination of nonsterile pharmaceuticals in public hospital settings. Ther Clin Risk Manag. 2010;6: 443-8. http://dx.doi.org/10.2147\%2FTCRM.S12253.

43. Abba D, Inabo H, Yakubu S, Olonitola O. Contamination of herbal medicinal products marketed in Kaduna Metropolis with selected pathogenic bacteria. Afr J Tradit Complement Altern Med. 2009; 6: http://dx.doi.org/10.4314/ ajtcam.v6i1.57076

44. Dashen MM, Chollom PF, Okechalu JN, Ma'aji JA. Microbiological quality assessment of some brands of cosmetics powders sold within Jos Metropolis, Plateau State. J Microbiol Biotech Res. 2011;1(2):101-6. http:// scholarsresearchlibrary.com/JMB-vol1-iss2/JMB-2011-1-2-101-106.pdf.

45. Behravan J, Bazzaz F, Malaekeh P. Survey of bacteriological contamination of cosmetic creams in Iran (2000). Int J Dermatol. 2005;44:482-5. doi:10.1111/j. 1365-4632.2005.01963.x.

46. Jarvis B, Reynolds AJ, Rhodes AC, Armstrong M. A survey of microbiological contamination in cosmetics and toiletries in the UK. J Soc Cosmet Chem. 1974;25:563-75. http://journal.scconline.org/pdf/cc1974/cc025n10/p00563p00575.pdf.

47. Abdelaziz AA, Ashour MSE, Hefni H, EL-Tayeb MO. Microbial contamination of cosmetics and personal care items in Egypt - eye shadows, mascaras and face creams. J Clinl Pharm Therape. 2008;14:21-8. http://dx.doi.org/10. 1111/j.1365-2710.1989.tb00217.x.

48. Hugbo PG, Onyekweli AO, Igwe I. Microbial contamination and preservative capacity of some brands of cosmetic creams. Trop J Pharm Res. 2003;2:229-34. http://www.bioline.org.br/pdf?pr03015.

49. Ratajczak M, Kubicka MM, Kamińska D, Sawicka P, Długaszewska J. Microbiological quality of non-sterile pharmaceutical products. Saudi Pharm J. 2015;23:303-7. doi:10.1016/j.jsps.2014.11.015.

50. Turnbull PCB. Bacillus. In: Baron S, editor. Medical Microbiology. Galveston: Dissertation, The University of Texas Medical Branch; 1996.

51. Kloos WE, Lambe DW. Staphylococcus. In: Balows A, Hausler Jr WJ, Herrmann KL, Isenberg HD, Shadomy HJ, editors. Manual of clinical microbiology. 5th ed. Washington D.C.: American Society for Microbiology; 1991. p. 222-37.

52. Farajnia S, Hassan M, Nezhadi SH, Mohammadnejad L, Milani M, Lotfipour F. Determination of indicator bacteria in pharmaceutical samples by multiplex PCR. J Rapid Methods Autom Microbiol. 2009;17:328-38. http://dx.doi.org/ 10.1111/j.1745-4581.2009.00154.x.

53. United States Pharmacopia, Microbiological Tests. In: The United States Pharmacopeia, $30^{\text {th }}$ revision and the National Formulary, $25^{\text {th }}$ edition (USPNF). Rockville, Maryland; United States Pharmacopeial Convention, 2007.

54. Jimenez L, Smalls S, Scalici C, Bosko Y, Ignar R, English D. Detection of Salmonella spp. contamination in raw materials and cosmetics/ pharmaceutical products using the BAX ${ }^{\text {TM }}$ system, A PCR-based assay. J Rapid Methods Autom Microbiol. 1998;6:67-76. http://dx.doi.org/10.1111/j. 17454581.1998.tb00185.x.

55. Samadi N, Alvandi M, Fazeli MR, Azizi E, Mehrgan H, Naseri M. PCR-Based detection of low levels of Staphyococcus aureus contamination in pharmaceutical preparations. J Biol Sci. 2007;7:359-63. http://198.170.104. 138/jbs/2007/359-363.pdf. 